\title{
Estado e direito no capitalismo: um debate entre o liberalismo e marxismo
}

\author{
Ednéia Alves de Oliveira ${ }^{1}$ \\ https://orcid.org/0000-0001-6550-7177 \\ ${ }^{1}$ Universidade Federal de Juiz de Fora, Programa de Pós Graduação em Serviço Social da Faculdade de Serviço Social de Juiz de Fora, \\ Juiz de Fora, MG, Brasil
}

\section{Estado e direito no capitalismo: um debate entre o liberalismo e marxismo}

Resumo: Esse artigo é resultado de uma pesquisa teórica sobre categorias como Estado e direito. Objetiva discutir de forma sumária, algumas definições sobre tais categorias no contexto atual, particularizando o debate entre liberalismo e marxismo nas relações sociais de produção capitalista. Nossa compreensão, é que tais categorias aparecem como substratos de caráter formal abstrato e não como elemento da vida concreta, real.

Palavras-chave: Estado. Direito. Capitalismo. Liberalismo. Marxismo.

\section{State and law in capitalism: a debate between liberalism and marxism}

Abstract: This article is the result of a theoretical research on categories such as State and Law.It aims to discuss, in summary form, some definitions about such categories in the current context, particularizing the debate between liberalism and Marxism in the social relations of capitalist production.. Our understanding is that these categories appear as substrates of an abstract formal character and not as an element of concrete, real life.

Keywords: State. Rights. Capitalism. Liberalism. Marxism.

Recebido em 03.08.2019. Aprovado em 11.02.2020. Revisado em 19.02.2020.

(C) O(s) Autor(es). 2020 Acesso Aberto Esta obra está licenciada sob os termos da Licença Creative Commons Atribuição-NãoComercial 4.0 Internacional (https://creativecommons.org/licenses/by-nc/4.0/deed.pt_BR), que permite copiar, distribuir e reproduzir em qualquer meio, bem como adaptar, transformar e criar a partir deste material, desde que para fins não comerciais e que você forneça o devido crédito aos autores e a fonte, insira um link para a Licença Creative Commons e indique se mudanças foram feitas. 


\section{Introdução}

Este artigo é resultado de uma pesquisa teórica sobre categorias como Estado e direito. Objetiva discutir de forma sumária, algumas definições sobre tais categorias no contexto atual, particularizando o debate entre liberalismo e marxismo nas relações sociais de produção capitalista. Inicialmente, salientamos que o Estado moderno surge das cinzas do feudalismo e tem sua consolidação com a publicação da Declaração Universal dos Direitos do Homem (1948) e as constituições federais promulgadas logo após a revolução francesa. A inspiração para a criação desses documentos encontra sua base nas obras de pensadores liberais contratualistas como Hobbes (1988) e Locke (1998) ou ainda no democrata-burguês Rousseau (1999, [2019?]), sendo seguido por outros autores de tradição liberal que defendem o contrato social como garantia para a liberdade e, como tal, para superar o estado de guerra ou de natureza e entrar na vida civilizatória, única forma de vida possível na modernidade, de acordo com estes autores. Para tal, as leis, implementadas pelo Estado, deverão ser o fundamento de consolidação da liberdade e, consequentemente do direito, na sua forma jurídica, como expressão máxima da coação dos homens e da normatização das regras de convívio social. Ou seja, a liberdade, a igualdade e a propriedade privada são premissas da ordem burguesa, cujo ente regulador será o Estado moderno emergente através de um aparato legal e normativo. Em um campo oposto, Karl Marx (2009, 2010, 2012a, 2012b) em algumas obras dos anos de 1840 adverte-nos sobre a natureza do Estado moderno e a falácia dos direitos propostos pela burguesia. Assim também o fazem outros autores da tradição marxista como Lenin (1978) e Pachukanis (1999) considerando o direito e o Estado como elementos de garantia da ordem burguesa.

Quando se delega ao Estado moderno a tarefa de garantir a liberdade, igualdade e propriedade privada, e estabelece o contrato social como relação social fundamental, cria-se mecanismos para permitir a compra e venda da mercadoria, inclusive a força de trabalho. Portanto, este Estado passa a ser o ente regulador da vida social criando instituições para favorecer a defesa da propriedade privada e garantir o direito civil e, em alguns casos, o direito político e social sem que, contudo, tais direitos possam incidir no processo de acumulação de capital. É nesse caminho que o Estado assume sua função normativa assegurando o jogo do mercado e os direitos civis e contratuais, hipostasiando a defesa da democracia e os direitos como algo tangível e em disputa, suscitando compreensões diferenciadas e que se alicerçam em concepções ideológicas que podem, como já ocorreu em diversos momentos da história, desencadear processos revolucionários ou ainda contrarrevolucionários como regimes totalitários e ditatoriais como demonstra o cenário político nacional e internacional marcado por eleições polarizadas entre a defesa da democracia burguesa e defensores de controle mais acentuado sobre os meios de comunicação, sobre as disciplinas escolares, sobre o poder judiciário e, inclusive sobre a perspectiva de criminalização de movimentos sociais dos mais variados tipos.

\section{Estado e direito na concepção liberal}

Mais de três séculos separam a obra de Hobbes do Estado hodierno. Contudo, sua atualidade nos exige um passeio pelas concepções desenvolvidas pelo autor e que serviu e servem de inspiração para muitos outros defensores do Estado liberal e neoliberal. É interessante ressaltar que os princípios do liberalismo clássico foram, à sua época, revolucionários. As propostas de liberdade e igualdade, delineados pelos defensores de tal doutrina, se colocavam contra o abuso monárquico e em defesa da vida. Segundo Hobbes (1988), um Estado soberano e defensor da paz era condição fundamental para o desenvolvimento da ordem e do progresso. Lembremos que Hobbes está escrevendo sobre as mudanças ocorridas na Inglaterra no século XVII e que para ele simbolizava uma guerra de todos contra todos, em que a disputa entre os monarquistas e liberais, culminava numa batalha crescente pelo poder. A morte do rei James I, decapitado em praça pública, colocou para ele a necessidade de discutir qual tipo de Estado poderia emergir num contexto de rupturas econômicas, políticas e sociais tão bruscas.

No desenvolver de seu pensamento, Hobbes (1988) deixa um legado bastante importante, sobretudo, no que se refere à natureza dos homens. Para ele, os homens são egoístas e movidos a interesses comuns. Tal justificativa se assenta no fato dos homens viverem em um Estado de guerra que legitima a disputa e a ganância desenfreada dos mesmos. Prossegue ele, afirmando que o homem busca sempre a satisfação imoderada e também utiliza da sabedoria para controlar os homens que governam, fazendo nascer as guerras e a desordem.

Para combater a desordem e mesquinhez dos homens, o autor destaca a necessidade de um Estado forte e soberano, capaz de adotar leis rigorosas que punam tais condutas e os obriguem a sair do estado de guerra para um estado civil. O conjunto de leis criadas pelos homens que governam, devem ser adotadas para evitar que o mal e a guerra prevaleçam sobre a paz e a liberdade. Esse poder soberano, representado pelo Estado, é resultado de um pacto em que a maioria institui a este o direito de representá-los. Seria para ele a 
multidão unida numa só pessoa: o Estado, senhor de todo o poder. O grande leviatã, deus mortal abaixo apenas do deus imortal (HOBBES, 1988).

Os súditos ao concederem ao Estado o poder de governar, delegam também o poder de criar leis, impostos, taxas e formas da propriedade privada. Para isto os direitos civis são enaltecidos pelo autor como sendo uma das questões fundamentais para estabelecer esta nova ordem. Ainda de acordo com Hobbes (1988), a constituição dos direitos civis será feita a partir dos homens que possuem posse, ou seja, os proprietários, pois somente eles podem definir os direitos de forma justa, uma vez que possuem interesses em comum. A mesma premissa sustenta o poder judiciário, que, segundo ele, deve ser nomeado pelo Estado para impedir a prevalência de interesses particulares e cada poder específico deve controlar o outro, evitando o abuso de poder. Embora os princípios do liberalismo estejam evidentes em Hobbes, há que salientar um dos elementos fundamentais que o liberalismo sempre defendeu: a democracia. Contudo, nos primórdios do Estado moderno a democracia ainda era compreendida como algo restrito, pois não incluía o sufrágio universal. Uma minoria escolheria seu representante, uma vez que a escolha está circunscrita a um grupo de homens proprietários.

Embora o pacto social envolva a maioria, cabe a esta apenas a tarefa de obedecer ao poder soberano representado pelo Estado, que por sua vez, não pode ser questionado de forma alguma. Quando os súditos o fazem são punidos com a lei severa criada sob o pretexto de garantir a paz e prevenir a desordem. Não por acaso, a liberdade para Hobbes é ausência de oposição. A concepção de liberdade é totalmente submissa ao poder da lei (HOBBES, 1988). Nesse sentido percebe-se que o autor equipara vontade e liberdade, pois as ações praticadas voluntariamente pelos indivíduos são resultados de sua vontade e liberdade. Não há coação, segundo ele, nessas ações. Ou seja, a lei não é uma forma de coação moral e legal para determinar as atitudes do homem, mas uma forma de liberdade, pois ninguém precisará usar da força para inibir abusos contra a vida e a propriedade. Nota-se aqui um aspecto fundamental do liberalismo e que será defendido ao longo dos séculos por vários outros pensadores liberais. Para Hobbes (1988), a liberdade dos súditos inclui a regulação da vida social através do Estado, permitindo a eles comprar e vender através de contratos, trabalhar, assim como escolher onde morar e educar os filhos. Notemos que este princípio da liberdade, de comprar e vender através de contratos formais e legais, está vinculado ao quesito da propriedade privada dos meios de produção que estabelecerá a liberdade dos súditos de vender sua força de trabalho para quem quiser. Desta forma está determinada a venda e compra da força de trabalho e que será o sustentáculo do modo de produção capitalista, denominado por Marx (2013) de acumulação de capital, sob a forma de trabalho não pago ao trabalhador, gerando a mais valia ou mais valor.

Em John Locke (1998), no seu Segundo Tratado sobre o Governo, os princípios do liberalismo serão tratados de forma mais refinada, o que o levou a ser considerado o pai de tais ideias. Para este autor (LOCKE, 1998), a liberdade, assim como para Hobbes (1988) é a base de sustentação da sociedade emergente. Contudo, uma distinção deve ser destacada, pois diferentemente de Hobbes (1988), a liberdade deve ser uma questão primordial, não devendo nenhum homem, pela força, tirar a liberdade de outrem. Contudo, é interessante ressaltar que a liberdade preconizada por Locke (1998) consiste em obedecer ao poder superior estabelecido pelo legislativo e não pelo monarca, como em Hobbes (1988). Ou seja, a base do contrato social de Locke (1998) reside no fato de todos os homens consentiram em obedecer a um determinado poder para escapar do estado de natureza.

Essa seria, segundo ele (LOCKE, 1998), a razão pela qual os homens escolhem viver em sociedade. Dessa forma, ao viver no estado social os homens deixam o estado de natureza que provoca apenas a insegurança e a guerra. As leis existem para estabelecer as regras da convivência em comum. Consiste, portanto, numa liberdade condicionada às leis impostas por um corpo político que estabelecerá as formas mais condizentes de se viver em sociedade. Isto inclui a própria preservação da vida, pois quem renuncia ao estado social, ou melhor, a vida em sociedade, abdica da liberdade e ao direito de preservação da vida. É interessante salientar que Locke (1998) define a lei como liberdade. Ou seja, todos aqueles que obedecem a lei estão vivendo em liberdade, pois aceitaram renunciar ao estado de natureza para se inserirem na sociedade civil.

[...] liberdade de seguir minha própria vontade em tudo quanto escapa à prescrição da regra e de não estar sujeito à vontade inconstante, incerta, desconhecida e arbitrária de outro homem. Assim como a liberdade da natureza consiste em não estar sujeito à restrição alguma senão à da lei da natureza. (LOCKE, 1998, p. 403, grifo do autor).

Os indivíduos que estão em sociedade civil, segundo o autor (LOCKE, 1998), são aqueles que unidos num corpo único seguem uma lei em comum, com poder de julgamento para atos e infrações contrárias. A lei serve como um elemento de autoridade, para punir aqueles que não seguem esta legislação comum. Todos aqueles que escolhem viver fora da sociedade civil é porque optaram por não seguir esta lei comum e igual para todos. 
Na sociedade política de Locke (1998) encontramos o corpo jurídico, responsável por decidir sobre leis e punições. Percebemos que o autor (LOCKE, 1998) está se referindo à preservação da propriedade privada, ao estabelecer que esta não pode ser invadida ou usurpada, sem que haja um corpo legal para julgar. O intuito fundamental do contrato social de Locke (1998) é a preservação da propriedade privada. Nesse sentido, suas premissas se assentam na propriedade, vida, bens e liberdade. Segundo ele, são esses os fins pelos quais os homens renunciam ao estado de natureza e vivem em sociedade política. Não por acaso, o corpo político que definirá as leis e regulamentações sociais está formado por homens que possuem bens e propriedades, tal qual em Hobbes (1988).

Foi Locke quem inspirou a Declaração de Direitos da Virginia, redigida em $1776^{1}$, nos Estados Unidos da América e que, posteriormente, servirá de inspiração para a Declaração dos Direitos do Homem em 1789 e também das constituições federais que a seguiram. Os princípios da liberdade, da vida e da propriedade privada serão as premissas que orientarão estas sociedades e sobre elas se assentará a lógica do direito liberal. Sobre as bases do liberalismo serão constituídos os poderes executivo, legislativo e judiciário, formando o Estado moderno. Embora Locke (1998) discorde de Hobbes (1988) quanto à forma de governo, pois se posiciona contrário ao despotismo e ao poder monarca, a democracia proposta por ele é bem limitada, pois se restringe aos homens de posse, excluindo significativas parcelas da população.

Ainda em relação aos contratualistas citamos a obra de Rousseau (1999). Em O Contrato Social (1721) o autor inova ao questionar alguns fundamentos tratados por Locke (1998) e Hobbes (1988), inicia sua obra questionando a ideia de liberdade, sustentada por um conjunto de leis que regularia a vida em sociedade. Para ele (ROUSSEAU, 1999), a defesa da liberdade é entendida como sendo um princípio de comum acordo entre todos os indivíduos que vivem em sociedade, sendo a lei apenas uma das formas e regras para estabelecer ou limitar tal liberdade. Notamos em Rousseau (1999) princípios muito próximos da democracia no seu sentido pleno, ou seja, da democracia como forma de proporcionar a liberdade dos indivíduos ou cidadãos sem levar em consideração a propriedade dos mesmos.

É em Rousseau ([2019?]) que encontramos um questionamento da igualdade sustentada pelos outros contratualistas. Para ele, a desigualdade social já se vislumbra na concentração da terra e nas formas de apropriação desta por uns, relegando outros a se subordinarem aos interesses da propriedade privada. Em seu Discurso sobre a origem da desigualdade escrito em 1754, o autor (ROUSSEAU, [2019?]) questiona a desigualdade social como fruto de um processo natural. Segundo ele, a desigualdade é construída historicamente, portanto é tarefa de indivíduos que decidiram cercar uma terra e apropriar-se dela. Tal feito, possível somente por leis reguladoras, estabelece o direito da posse que uns passam a usufruir sobre outros na sociedade.

Concebo na espécie humana duas espécies de desigualdade: uma, que chamo de natural ou física, porque é estabelecida pela natureza, e que consiste na diferença das idades, da saúde, das forças do corpo e das qualidades do espírito, ou da alma; a outra, que se pode chamar de desigualdade moral ou política, porque depende de uma espécie de convenção, que é estabelecida ou, pelo menos autorizada pelo consentimento dos homens. Conste esta nos diferentes privilégios que gozam alguns com prejuízo dos outros, como ser mais ricos, mais honrados, mais poderosos do que outros, ou mesmo fazerem-se obedecer por eles (ROUSSEAU, 1999, p. 39).

Portanto, Rousseau (1999) definirá a desigualdade como um construto social e não como algo naturalizado. Ao contrário de Hobbes (1988) que considerava o homem mau por natureza, Rousseau (1999) considera o homem bom por natureza e a sociedade e suas convenções que o transformará em sujeito egoísta. É neste processo que irá moldar-se o caráter do homem e também das leis. O direito surge deste contrato social, fundador de uma relação social baseada na capacidade legal de organizar a vida em sociedade. Contudo, a lei não seria para ele a imposição da vontade de uns sobre outros, mas resultado da vontade geral e não da vontade de todos. Segundo Rousseau (1999), este princípio é baseado na racionalidade, pois quando obedeço as leis, obedeço a mim mesmo, o que torna o indivíduo livre.

A vontade geral em Rousseau (1999) é o momento máximo da democracia, pois significa que todos os indivíduos concordam com as leis e regras vigentes. Ao contrário da vontade de todos que faz com que prevaleça interesses particulares sobre o interesse em comum. Suas ideias tiveram grande influência na revolução francesa. Destacamos também que, apesar dos princípios da democracia preconizados pelo autor, a revolução francesa foi tomada por ideais totalitários, em que a vontade de todos prevaleceu sobre a vontade geral, como ficou evidenciado durante o período do Terror na França.

Portanto, o papel do soberano é fazer prevalecer a vontade geral construída racionalmente pelos indivíduos sem favorecer a nenhuma necessidade particular. Neste sentido, o pacto social seria uma convivência pacifica e consciente em que cada um abre mão de algo em prol dos interesses gerais. Apesar da defesa da 
liberdade, Rousseau (1999), assim como os outros contratualistas, entende a necessidade de uma sociedade regida por leis e direitos construídos socialmente. Sua referência quanto à obrigação dos cidadãos a seguirem os deveres básicos da boa convivência, deixa-nos a dúvida sobre o princípio de liberdade preconizado pelo autor (ROUSSEAU, 1999). Isso porque, se a convivência pacífica deve ser construída sobre leis e deveres pressupõe uma liberdade imposta por leis institucionalizadas e que, no nosso entendimento, pode significar a obediência pela simples obediência. Em comparação com os outros dois contratualistas, Rousseau é bem mais democrático, mas não consegue pensar a sociedade sem um conjunto de leis e regras para fazer com que o homem possa desenvolver seu princípio civilizatório e ter acesso aos direitos.

Ao pensamento liberal dos contratualistas vai somar-se o pensamento econômico de Adam Smith (1996). Sua única citação sobre a mão invisível em A Riqueza das Nações ${ }^{2}$ passou a ser a expressão fajuta cultuada por liberais afinados com os interesses da livre iniciativa e da exploração do trabalho e a não intervenção do Estado na economia, hipostasiando uma concepção de que o mercado pode regular os egoísmos e otimizar as relações comerciais entre os homens. Fato é que Smith (1996) está se contrapondo a um período mercantilista em que o Estado controlava as relações comerciais, impedindo, na opinião dele, que os indivíduos pudessem ascender economicamente e concorrerem em busca de melhores condições e oportunidades de negócios. Portanto, para ele (SMITH, 1996), o mercado deveria ser a instituição reguladora e não o Estado, pois o mercado atuaria aglutinando os egoísmos em prol do bem da nação, promovendo sua prosperidade. Notemos que para Smith (1996, p. 74) é o egoísmo e a concorrência que fazem com que uma nação prospere e atinja sua riqueza, "Não é da benevolência do açougueiro, do cervejeiro ou do padeiro, que nós esperamos nosso jantar, mas da consideração que eles têm pelo seu próprio interesse". Essa união entre liberalismo político e econômico resultará na concepção de Estado burguês e na lógica de um direito assentado no individualismo, no egoísmo, na livre concorrência e na defesa da propriedade privada. Serão sobre essas premissas que Marx e alguns marxistas irão se contrapor conforme veremos adiante.

\section{Estado e direito na tradição marxista}

As proposições dos contratualistas tiveram sua expressão na constituição da Declaração de Direitos do Homem e do Cidadão, publicada na França em agosto de 1789. A defesa dos direitos civis preconizados pelos autores supracitados (HOBBES, 1988; LOCKE, 1998; ROUSSEAU, 1999) adquire a forma de uma carta que deverá reger a lógica contratual social. O temor da burguesia em perder o poder econômico e político recém-conquistados, reflete-se no segundo e último artigo da declaração, ao enfatizar a propriedade privada como um direito inalienável (UNIVERSIDADE DE SÃO PAULO, [2019?]). Notamos que na referida declaração não há referência a direitos econômicos ou sociais, apenas uma série de direitos civis e políticos que seriam assegurados pelo direito jurídico, instância máxima de regulação da vida social. Essa declaração considerada à época como um marco revolucionário da defesa da liberdade e da democracia, na verdade ocultava os interesses de uma classe emergente preocupada em preservar seu poder econômico e político evitando qualquer ameaça advinda das classes operárias (UNIVERSIDADE DE SÃO PAULO, [2019?]). Em seu ensaio Para a questão judaica, Marx (2009) vai analisar a declaração de 1789 considerando-a como um instrumento de legitimação da ordem burguesa, o autor irá ressaltar que a defesa dos direitos humanos preconizada no documento, é uma igualação do homem ao homem burguês e membro da sociedade em individuo egoísta e proprietário. Prosseguindo em sua crítica, Marx (2009) destaca o segundo item da declaração que trata dos direitos inalienáveis como a liberdade, a segurança e a propriedade privada. Para ele (MARX, 2009), a liberdade proposta seria a separação entre os homens para um indivíduo limitado a si mesmo, em oposição ao pressuposto da fraternidade decantada pela revolução burguesa. No que se refere à segurança, Marx (2009) revela-nos a natureza do Estado burguês como instituição repressora e garantidora da propriedade privada, por isso os aparatos legais e policialescos para proteger não aos indivíduos, mas apenas a propriedade privada. Para tal, o autor (MARX, 2009) descontrói a ideia da propriedade privada como direito natural, asseverando, assim como Rousseau (1999), que esta é resultado de um processo social e histórico.

Em Pachukanis (2017), encontramos uma definição que explicita essa relação do homem egoísta e separado de si mesmo. Recorrendo ao próprio Marx (2009) em seu ensaio Sobre a Questão Judaica (1844), o autor divide o direito em dois aspectos: o direito subjetivo, que expressa essa relação e egoísmo de separação do homem de si mesmo, convertendo-o a mero membro da sociedade civil, e o direito objetivo "expressão do Estado burguês como um todo." (PACHUKANIS, 2017, p. 111). Ou seja, momento político que adquire universalidade quando se contrapõe a seus próprios elementos. O autor (PACHUKANIS, 2017) vai destacar que o problema do direito subjetivo e do direito objetivo, é alinhado a contradição entre o home egoísta, burguês e o homem político membro do Estado. Nesse sentido, a contradição está no âmbito do direito privado e do direito 
público, visto que são momentos que a lógica formal da dogmática jurídica não consegue solucionar. As instituições burguesas de caráter estatal não conseguem criar expressões que rompam com esse paradoxo, pois seria romper com a própria lógica do direito jurídico.

Não por acaso, a Declaração dos Direitos do Homem e do Cidadão foi um instrumento para consolidar o ser individual separado dos demais membros da comunidade, tornando-os egoístas e defensores dos direitos privados. A crítica ao direito e a democracia burguesa também pode ser encontrada em outras obras do autor. Nas Glosas Críticas (1844) e na Crítica ao Programa de Gotha (1891) só para citar algumas, encontramos reflexões que nos permitem balizar nossa argumentação. No primeiro texto mencionado, Marx (2010), cita como a Inglaterra assumiu posturas repressivas e punitivas no controle da pobreza. Embora o texto trate de uma crítica que o autor faz ao prussiano e suas análises sobre a situação da Prússia e a greve dos tecelões da Silésia, ele aproveita para demonstrar que um Estado avançado como a Inglaterra não conseguiu eliminar o pauperismo com suas medidas administrativas ou caritativas, ou melhor dizendo, pela via da política. Pelo contrário, foi preciso criar mecanismos mais punitivos para estabelecer a obediência civil da classe trabalhadora para aceitar sua condição de pobre e respeitar a doutrina do trabalho imposta pela burguesia. Para Marx (2009), as leis mostram seu caráter doutrinador e garantidor da propriedade privada, proporcionando a liberdade do contrato de trabalho e da propriedade privada.

O Estado, portanto, será o administrador destas ameaças, aprimorando e reforçando o direito jurídico público e privado como mecanismo do controle social. Nestas duas obras (MARX, 2010, 2012b) a crítica de Marx ao Estado adquire tons mais enfáticos, pois percebe que as instâncias administrativas do poder estatal estão em consonância com uma perspectiva de adequação da ordem e que as políticas e legislações trabalhistas da época apenas evocavam o direito da burguesia continuar explorando os trabalhadores e manter inviolável o direito da propriedade privada. Para Marx e Engels (1998) a presença do Estado revela a sua natureza, pois seus pressupostos tendem a garantir interesses daqueles que possuem a propriedade privada dos meios de produção, sendo um agente de regulação a favor dos interesses particulares dos proprietários. Em a Crítica ao Programa de Gotha redigido anos depois, Marx (2012b) questiona o entendimento do partido social democrata sobre salário justo e igualdade social. No seu entendimento não há possibilidade de tratamento igual para pessoas que apresentam capacidades e necessidades desiguais. Portanto, a desigualdade social não é um processo natural, mas sim socialmente construído, tendo como garantidor deste momento, as leis e regulamentações criadas pelo Estado classista. Em Marx (2013) o conflito não se resolve a partir do Estado, este apenas cria formas de regular os conflitos, criando mecanismos para ocultar esta guerra civil mais ou menos oculta entre burguesia e proletariado. O Estado é, portanto, um regulador do antagonismo de classes, com uma natureza de classe e não de neutralidade como asseveram os liberais. Igualdade seria apenas uma concepção abstrata, pois o homem não se iguala pela via do Estado burguês e nem pela concepção formal de uma igualdade jurídica e natural.

\section{A essa concepção minimalista}

\section{de democracia e de direito} social soma-se o

\section{conservadorismo de ideias}

$$
\text { religiosas e afinadas com }
$$

valores positivistas como

$$
\begin{gathered}
\text { família, ordem, progresso e } \\
\text { religião. }
\end{gathered}
$$

Sobre tal tema, Lenin (1978) vai reforçar a teoria de Marx (2010) ao afirmar que o Estado é o produto inconciliável das classes. Como ele nasce para reprimir as contradições das classes, vai ser um Estado que legisla em prol de uma classe especifica: aquela que detém os meios de produção. Cria desta forma mecanismos para explorar a classe trabalhadora, assim como os Estados anteriores foram os agentes de exploração dos escravos e dos servos, assim o é o Estado moderno na exploração do trabalhador assalariado.

Pachukanis (2017) assinala que o estado de paz torna-se uma necessidade quando a troca adquire certa regularidade. As leis criadas pelo Estado visavam estabelecer normas e regras para controle das relações mercantis. Criase a necessidade de consolidar a paz de mercado e, sem leis, dificilmente essa paz seria alcançada, pois como salientara Smith (1996), a concorrência e o egoísmo eram elementos a proporcionar um mercado em crescimento e prosperidade. Não por acaso, Hobbes (1988) e Locke (1998) enfatizam a necessidade de homens possuidores de bens e propriedade para criar leis e faze-las serem implementadas, impedindo que o homem comum, o trabalhador, vendedor e proprietário de sua força de trabalho, pudesse criar ou legislar em prol dos seus próprios interesses. É com vistas a este controle que os direitos políticos foram ampliados bem mais tardiamente que os direitos civis. Como expressão da maior liberdade política, o direito de voto, abriria a possibilidade de uma representação política que extrapolava os interesses de uma única classe. 
A resistência da burguesia, segundo Barbalet (1989), permitiu que somente no início do século XX, em alguns países, fosse consolidado o sufrágio universal ${ }^{3}$. Na Inglaterra, principal berço do capitalismo, a universalidade do sufrágio data de 1928. Em outros países ainda mais tardiamente, como o caso do Brasil, onde o sufrágio universal ocorreu somente no final dos anos de 1980 com a inclusão dos analfabetos pela Constituição Federal de $1988^{4}$ (BRASIL, 1988). Sobre tal argumento Lenin (1978) afirma ter sido o sufrágio universal uma arma da burguesia, garantido legalmente pelo Estado para exercer o controle sobre a classe trabalhadora, sob a falsa ideia de que o direito de voto seria capaz de representar a vontade da maioria dos trabalhadores e para assegurar a realização desta vontade por um Estado comandado pela classe dominante economicamente.

Ao realizar o direito de voto, o direito político soma-se ao direito civil como expressão da democracia burguesa. Cidadania passa a ser considerado o direito de votar, esquecendo-se de direitos fundamentais como comer, beber, dormir e ter moradia. Ao enfatizar direitos civis e políticos relega os direitos econômicos à lógica do mercado como instância de promoção da igualdade e justiça social, portanto, exclui o Estado de promover mecanismos de subsistência dos trabalhadores. Neste sentido, a democracia proposta pelos liberais não se materializa, pois como salientou Borón (2006) não pode existir democracia onde homens e mulheres tenham que vender sua força de trabalho por um prato de comida. Wood (2011) também ressalta que o capitalismo pode conviver perfeitamente com a defesa dos direitos, desde que estes não interfiram no processo de acumulação. Não é por acaso que a defesa dos direitos perpassa basicamente a luta pelos direitos civis. Tal fato está expresso na Declaração Universal dos Direitos Humanos (ORGANIZAÇÃO DAS NAÇÕES UNIDAS, 2009), publicada em 1948, logo após a segunda grande guerra e o holocausto judeu. Seu caráter liberal e jusnaturalista está expresso já no primeiro artigo quando resgata a ideia de que todos os homens nascem iguais em dignidade e direitos, e apela para a fraternidade com que devemos agir em relação aos outros. Também ressalta o direito de propriedade e sua inviolabilidade. Estes princípios também serão expressos nas constituições federais modernas. O destaque é para as liberdades individuais que incluem a liberdade de religião, associação, locomoção, sexual, etc., ou seja, a lógica dos direitos humanos hipostasia a liberdade sem qualquer relação com a vida objetiva dos sujeitos, denotando mais uma vez a separação do homem e do cidadão, remetendo a lógica do homem individual, separado de si mesmo. Sua inspiração é estritamente liberal, no sentido proposto por Hobbes (1988) e Locke (1998) e criticado por Marx em Para a questão judaica, pois asseguram a liberdade, a propriedade e a segurança, respaldadas pelo direito jurídico (OLIVEIRA, 2015). Aqui vigora a ideia de que todos os homens são iguais perante a lei e só obedecendo a esta será livre para viver plenamente seus direitos.

Para legislar em prol dos direitos civis, amplia-se a representação parlamentar. Lenin (1978) considera que, ao contrário dos que defendiam os revisionistas, corrente exponenciada por Bernstein (1850-1932) e amplamente difundida na segunda internacional, o parlamentarismo é um instrumento da democracia burguesa, pois pressupõe o reformismo como base das mudanças econômicas e sociais. Quando analisa o parlamentarismo através das leituras de Marx sobre a Comuna de Paris, Lenin (1978) enfatiza este sistema de governo como uma mera condição da burguesia de permitir ao proletariado escolher seus representantes, isto é, escolher qual membro da burguesia que esmagará o povo no parlamento. Ou seja, ainda que o direito de ser votado tenha possibilitado a eleição de membros da classe operária ao poder, estes acabam sendo cooptados por interesses que não são os da classe a qual deveriam representar. Exemplo é o financiamento de campanhas de parlamentares no Brasil por empresas privadas, as quais os parlamentares vão representar em detrimento do interesse da classe trabalhadora.

Neste sentido, a democracia burguesa para Lenin (1978) pode ter o mesmo significado de uma monarquia constitucional, pois não prevê a superação do Estado, mas a defesa dos interesses da classe dirigente por meios de leis e normas de cunho econômico que visa salvaguardar o capitalismo e suas instâncias e permitir a acumulação de capital. Em tempos de ofensiva do capital, essa realidade se torna mais evidente, embora travestida de ideias novas, como o neoliberalismo. Suas premissas carregam em si algumas das características do liberalismo clássico, tanto econômico quanto político, como a ênfase na igualdade civil e jurídica, na liberdade, na defesa de um Estado neutro e mínimo, na individualidade, na meritocracia e, sobretudo, na democracia parlamentar. O direito de voto aparece como expressão máxima da realização desta democracia e liberdade que, por sua vez é controlada por uma série de leis e normas de regulação da vida social. O proibicionismo aparece como elemento crucial das relações sociais, amparados pela ideia de que sem leis não há civilidade, ou melhor dizendo, sem lei não há liberdade. No plano econômico, o liberalismo de mercado é a reprodução dos ideais da meritocracia e do oportunismo, uma vez que oferece igualmente a todos, condições de superar a desigualdade social. Ou seja, o mercado aparece como elemento substancial de promoção da igualdade e justiça social, apoiado por ideais de individualismo exacerbado.

A essa concepção minimalista de democracia e de direito social soma-se o conservadorismo de ideias religiosas e afinadas com valores positivistas como família, ordem, progresso e religião. São essas ideias que 
florescem em momento de crise aguda do capital e permitem a ascensão de ideais totalitários em que o sujeito privado, dotado de liberdade e igualdade jurídica continua em contradição com o direito público, pois o Estado burguês mescla as necessidades econômicas da ordem com a vida privada do individuo, implementando formas de controle que visam exclusivamente a garantia do estado da paz para o progresso da acumulação de capital.

Justifica-se, assim, a ausência de políticas sociais já defendidas pelos liberais clássicos, pois estas afetariam a livre concorrência entre os indivíduos. Portanto, os direitos sociais são eliminados pela otimização da economia e das políticas macroeconômicas de crescimento econômico. Ancoradas por um discurso conservador que nos dias atuais adentra o mundo político e econômico, toda e qualquer intervenção estatal no plano social esbarra nas propostas de ajuste fiscal imposta pelas agências multilaterais. Nessa perspectiva, o Estado de bem-estar social, vigente em alguns países da Europa central, é objeto de duras críticas em razão do avanço do desemprego e da crise imigratória que assola tais países, ressuscitando ideais fascistas e totalitários como na Itália, Hungria, Turquia, entre outros. Para muitos pensadores burgueses, o excesso de políticas sociais implementadas pelo Estado de bem estar social, apenas favoreceu a preguiça e a vadiagem, pois as políticas de renda impediram os pobres de alcançarem sucesso através de seu próprio mérito.

Scruton (2015) considera que a concessão de benefícios ao longo do pós-segunda guerra mundial, criou uma categoria de indivíduos que se acostumou a viver sobre o trabalho de outrem, fugindo de qualquer obrigação e impondo aos demais a responsabilidade de sustentar esta camada de pessoas que se recusam a viver com responsabilidade enquanto outros o fazem. Para ele (SCRUTON, 2015), os impactos disto não são fundamentalmente econômicos, mas criam conflitos na forma de pertencimento, pois causa antagonismo entre os cidadãos responsáveis e aqueles que não o são. Ainda segundo o mesmo autor, os serviços de saúde, educação, moradia, previdência social e as políticas de trabalho e assistência social, evidenciaram a incapacidade de os governos sustentarem estas benesses em face do gigantismo do Estado e a ausência de recursos para garantir estas políticas e serviços. Notemos que o autor (SCRUTON, 2015) refere-se aos impactos econômicos e financeiros do Estado social europeu que, segundo ele, não pode mais ser financiado à custa do trabalho daqueles que tem disposição para trabalhar. Não por acaso desde 1990 há uma inversão do estado de bem estar para um estado do Workfare, centrado na ideia do trabalho como única possibilidade de inclusão social. Ou seja, o direito aqui é aquele que afirma em seus fundamentos os valores sociais do trabalho e da livre iniciativa.

Como o trabalho não pode ser garantido a todos os indivíduos, em face da dinâmica do modo de produção capitalista ser excludente e desigual, o emprego torna-se restrito a alguns indivíduos, gerando uma massa de sobrantes e descartáveis, dependentes de políticas sociais que não são mais oferecidas pelo Estado. Diante do avanço do desemprego e da pobreza, sobretudo em países da periferia capitalista como o Brasil, a solução também pode aparecer em forma de ideais totalitários travestidos de um discurso humanizador do capital e de construção do estado da paz, alcançável pela eliminação dos sujeitos que desobedecem ao contrato social e à construção da paz civilizatória. Ao invés de políticas sociais, políticas punitivas ou armamentistas incrementadas pela lógica do bom pobre ou do mau pobre, sendo destinado a este último a bucha do canhão. O que nos remete a considerar que o Estado moderno desde Hobbes até os dias atuais, surgiu para atender aos interesses da classe economicamente dominante, e tudo o que veio depois se materializa para perpetuar esta máxima. Ou seja, o capitalismo é como o Fausto de Goethe (1991), egoísta, narcisista, disposto a vender sua alma ao diabo, no caso Mefistófeles, para seduzir e destruir tudo e todos que o circundam com o discurso sedutor da inclusão e da garantia dos bons costumes.

\section{Considerações Finais}

Se Fausto (GOETHE, 1991), para criar um mundo novo destrói as convicções e crenças dos que o cercam, não é diferente com o capitalismo hodierno. As fraseologias consagradas pelos burgueses vêm atravessando as décadas e paulatinamente são incorporadas no ideário comum sem críticas ou compreensão da real natureza dessas assertivas. É o que notamos quando se trata da defesa dos direitos, da democracia e da liberdade. Ou seja, estas premissas são comumente consideradas como algo factível de serem consagradas no modo de produção capitalista. Portanto, faz-se mister compreender como os direitos, a democracia e o Estado, atuam de forma a mascarar o seu real significado.

Nesse sentido, direitos podem ser apenas direitos civis e a democracia uma permissividade da explanação desses direitos e não da real repartição da riqueza socialmente produzida, limitando-se apenas a um apelo eleitoreiro, que reforça um parlamentarismo maculado por interesses particulares e classistas e legitima o Estado como ente que tudo controla e tudo pode em nome do capital, o grande Leviatã de Hobbes. Portanto, Lenin (1978) estava correto quando compreendeu que o parlamentarismo burguês é apenas a expressão de uma dominação disfarçada em que a classe trabalhadora acredita eleger representantes que possam reverter 
as condições de sua classe. Ou ainda como destacou Pachukanis (2017), o Estado ao defender os interesses da classe dominante amplia as instituições reguladoras para controlar a classe trabalhadora. O limite será quando a luta de classes for além das reivindicações e manifestações reformistas, e obrigar o capital a deixar de lado a farsa do Estado de direito e a revelar a sua real essência que é a violência organizada sobre a classe trabalhadora. Para muitos este limite já chegou, pois o fascismo capitalista está como Mefistófeles, apenas esperando para levar o que resta da vida do trabalhador sob a máscara do bem comum.

\section{Referências:}

BARBALET, J. M. A cidadania. Lisboa, Portugal: Estampa, 1989.

BORÓN, A. Filosofia política e crítica da sociedade burguesa: o legado teórico de Karl Marx. In: BORÓN, A. (org.). Filosofia política moderna: de Hobbes à Marx. Buenos Aires, Argentina: Consejo Latiamericano de Ciencias Sociales; São Paulo: Departamento de Ciência Política/USP, 2006. p. 287-330.

BRASIL. [Constituição (1988)]. Constituição da República Federativa do Brasil. Brasília, DF: Senado Federal: Centro Gráfico, 1988. DIREITOS HUMANOS. Declaração dos direitos da Virgínia. [S. l.], c1995. Disponível em: http://www.dhnet.org.br/direitos/anthist/ dec1776.htm. Acesso em: 20 ago. 2019.

GOETHE, J. W. Fausto. Madrid, España: Club Internacional del Libro, 1991.

HOBBES, T. M. Leviatã ou matéria, forma e poder de um estado eclesiástico e civil. 4. ed. São Paulo: Nova Cultural, 1988.

LENIN, V. O Estado e a revolução. São Paulo: Hucitec, 1978.

LOCKE, J. Dois tratados sobre o governo. São Paulo: Martins Fontes, 1998.

MARX, K. Para a questão judaica. São Paulo: Expressão Popular, 2009.

MARX, K. As lutas de classes na França. São Paulo: Boitempo, 2012a.

MARX, K. Crítica do Programa de Gotha. São Paulo: Boitempo, 2012b.

MARX, K. Glosas críticas ao artigo "O rei da Prússia e a reforma social”. De um prussiano. In: MARX, K.; ENGELS, F. Lutas de classes na Alemanha. São Paulo: Boitempo, 2010. p. 25-52.

MARX, K., ENGELS, F. Manifesto do Partido Comunista. Belo Horizonte: Liga Operária e Camponesa, 1998.

MARX, K. O Capital: crítica da economia política: livro I: processo de produção do capital. São Paulo: Boitempo, 2013.

OLIVEIRA, E. A. Os direitos na ordem burguesa: entre a farsa e a tragédia. In: Oliveira, E. A.: LAMAS, F. G. (org.). Pensamento crítico e ciências humanas: um caminho para Marx. Rio de Janeiro, Lumen Juris, 2015, p. 65-87.

ORGANIZAÇÃO DAS NAÇÕES UNIDAS. Declaração Universal dos Direitos Humanos. Rio de Janeiro: Centro de Informação das Nações Unidas para o Brasil, ago. 2009. Disponível em: https://nacoesunidas.org/wp-content/uploads/2018/10/DUDH.pdf. Acesso em: 20 abr. 2019.

PACHUKANIS, E. Teoria geral do direito e marxismo. São Paulo: Boitempo, 2017.

ROUSSEAU, J. J. Discurso sobre a origem da desigualdade. Edição eletrônica: Ed. Ridendo Castigat Mores, [2019?]. Disponível em: http://www.ebooksbrasil.org/adobeebook/desigualdade.pdf. Acesso em: 15 jun. 2019.

ROUSSEAU, J. J. O contrato social: princípios do direito politico. 3. ed. São Paulo: Martins Fontes, 1999.

SCRUTON, R. Como ser um conservador. Rio de Janeiro: Editora Record, 2015.

SMITH, A. A riqueza das nações: investigação sobre suas naturezas e suas causas. São Paulo: Nova Cultural, 1996. v. 1. (Os Economistas).

UNIVERSIDADE DE SÃO PAULO. Biblioteca Virtual de direitos humanos. Declaração de direitos do homem e do cidadão. [S. l.], [2019?]. Disponível em: http://www.direitoshumanos.usp.br/index.php/Documentos-anteriores-\%C3\%A0-cria\%C3\%A7\%C3\%A3oda-Sociedade-das-Na\%C3\%A7\%C3\%B5es-at\%C3\%A9-1919/declaracao-de-direitos-do-homem-e-do-cidadao-1789.html. Acesso em: 19 fev. 2020.

WOOD, E. M. Democracia contra capitalismo: a renovação do materialismo histórico. São Paulo: Boitempo, 2011.

\section{Notas}

1 No seu primeiro item, a Declaração de Direitos da Virgínia (DIREITOS HUMANOS, c1995) estabelece a igualdade jurídica e a liberdade como direitos inatos. Ainda define o direito de adquirir e possuir propriedade através de leis que inibissem a usurpação da propriedade pelos cidadãos que a possuíssem. Essa declaração inspirou todas as outras e segue um fio condutor comum: liberdade, paz, segurança e propriedade privada, embora não na ordem apresentada por nós.

2 Smith (1996, p. 438) menciona o termo somente no livro 4, capítulo 2.

3 Sobre a questão do sufrágio universal, ler Marx (2012a).

4 A Constituição Federal de 1988 permitiu aos analfabetos o direito de votar, mas não de serem votados. 


\section{Ednéia Alves de Oliveira}

oliveiraedneia21@yahoo.com

Doutora em Serviço Social pela Universidade do Estado do Rio de Janeiro (UERJ)

Professora da Faculdade de Serviço Social da Universidade Federal de Juiz de Fora (FSS/UFJF)

\section{UFJF}

Rua José Lourenço Kelmer, s/n - São Pedro

Juiz de Fora - MG - Brasil

CEP: 36036-900

\section{Agradecimentos}

Aos colegas que trabalham arduamente para construir e manter os periódicos da área de Serviço Social com qualidade teórica e rigor crítico e necessário em tempos de ofensiva do capital.

\section{Agência financiadora}

Não se aplica.

\section{Contribuições da autora}

Não se aplica.
Aprovação por Comitê de Ética e consentimento para participação

Não se aplica.

\section{Consentimento para publicação}

Consentimento da autora.

Conflito de interesses

Não há conflito de interesses. 